It was not our intention to imly that cytopathic events only start with bacterial adhesion It is self evident that the loss of microvilli which precedes and facilitates close attachment must be a manifestation of cell injury. It seems, however, that cell adhesion is required for more severe cytopathic effects and possibly the induction of an immune response. This could explain the finding of $H$ pylori in the mucus layer above apparently normal corpus mucosa in some cases of antral gastritis. We do not agree that bacterial adherence is likely to be a late event after epithelial injury sufficient to cause mucin depletion and cellular degeneration. On the contrary, we were surprised at the lack of degeneration seen ultrastructurally in surface cells bearing adherent organisms. Furthermore, the accumulation of actin filaments seen at bacterial attachment sites and most pronounced beneath adhesion pedestals presupposes a degree of cytoplasmic integrity and metabolic homoeostatis incompatible with advanced degeneration.

Finally, with regard to bacterial survival, there would be little biological advantage to be gained from a mechanism which involved attachment to degenerate cells soon to be exfoliated into the gastric lumen.

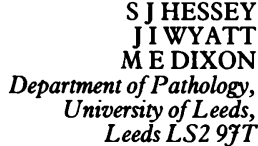

1 Caselli M, Figura N, Trevisani L, et al. Patterns of physical modes of contact beween Campylobacter pylori and gastric epithelium: implications abou the bacterial pathogenicity. Am $\mathcal{F}$ Gastroentero 1989; 84: 511-3.

2 Smoot DT, Mobley HLT, Gilliam T, Phelps P, Resau JH. Pedestal formation of Helicobacter (Campylobacter) pylori with gastric epithelial cells in vitro may require actin polymerization. Gastroenterology (in press).

\section{An old student's memories}

SIR, - In reference to the birthday tribute to Sir Francis Avery Jones (Gut 1990; 31: 489-93) I would like to pay tribute to my chief Sir Francis Avery Jones, father of modern British gastroenterology.

I was introduced to him on my first arriving in Britain as a British Council postgraduate scholar in 1965, by Professor Hugh Morgan to whom I was medical registrar in Khartoum University Hospital. He was surrounded by his distinguished collaborators Kellock, Rowland, Richard Doll, Edward, Shiner, Lennard-Jones, Misiewicz, and Langman. I joined him as clinical assistant, and then attended the second gastroenterology course conducted by the British Postgraduate Medical Federation in various London teaching hospitals, including the Central Middlesex, for 12 postgraduates from a dozen different countries, Sudan being represented for the first time. He introduced me to Sidney Truelove in Oxford, with whom I worked as honorary registrar to study aspects of ulcerative colitis, Crohn's disease, and the irritable bowel syndrome; to Sir Christopher Booth at Hammersmith for absorption and metabolic studies; and to Dame Sheila Sherlock for experience in hepatology.

His working day was always full and his tolerance and abilities in late middle age excelled ours in the prime of youth. The rounds, teaching sessions, and clinical meetings were so instructive that no one ever felt monotony or boredom. His approach was so modest, with interest and excitement in everyone's contribution. He thus created in all the desire and curiosity for more teaching and more learning. I concur with Lennard-Jones's statement: 'He poked, rather than palpated, the abdomen in a rapid and seemingly casual manner but he always knew what he was looking for. His skill was born of the listening ear, immense experience and uncanny intuition.'

When we finished late at Central Middlesex he would drop us at our residence in his Rolls Royce. His frequent unforgettable cosmopolitan gatherings at 44 Cleveland Square for postgraduates, staff, and frequent continental and overseas visitors were happy occasions and created everlasting friendships between people from all parts of the world. It was an opportunity not to be missed including the personal experience which you never see hear, or read about anywhere. One of the dictums he taught me was: There are two types of duodenal ulcers, the bleeding ulcer and the painful ulcer; the bleeding is painless and the painful does not bleed; if they die of their ulcers it is through exsanguination in the former and perforation in the latter.

You will find graduates of the Avery Jones school in every corner of the world; they naturally differ in nationality, skin colour, habits, religion, and mother tongue, but they are unanimously similar in one thing, and that is their affection for Avery.

F N SHAMSEDDIN Wad Medani Teaching Hospital, PO Box 52 Sudan

\section{Obscure anaemia and hepatic dysfunction in} Castleman's disease

SIR,-The fascinating case of Castleman's disease described by Featherstone et al (Gut $1990 ; 31: 834-7)$ bears a striking similarity to that of a young woman under our care.

She had a long history of vague ill health from the age of 20 . Clinical examination was normal but she was found to have moderate anaemia (haemoglobin 8-10 g/dl), hyperglobulinaemia (IgG 55.8 g/1, IgA 6.2 g/l, IgM $3.6 \mathrm{~g} / \mathrm{l}$ ) and a raised erythrocyte sedimentation rate $(100-130 \mathrm{~mm}$ in the $1 \mathrm{st} \mathrm{h})$. Bone marrow examination was essentially normal and a haematological diagnosis of anaemia of chronic disease was made. The patient continued to complain of malaise and the abnormal laboratory tests persisted.

Ten years after the onset of her symptoms she developed generalised pruritus and liver function tests were abnormal (alkaline phosphatase $912 \mathrm{U} / 1, \gamma$ glutamyl transferase $122 \mathrm{U} / \mathrm{l}$, alanine aminotransferase $25 \mathrm{U} / 1$, bilirubin 6 $\mathrm{mmol} / \mathrm{l})$. Liver biopsy specimen showed mild non-specific inflammatory changes. At this stage a Kveim test was positive and a course of prednisolone was given. There was no response by clinical or laboratory criteria and steroid treatment was withdrawn.

Three years later, 13 years after the initial presentation, the patient developed menorrhagia. An ultrasound scan of the pelvis showed a large paraovarian mass. At laparotomy a $10 \mathrm{~cm}$ retroperitoneal tumour with enlarged para-aortic and parailiac lymph nodes was resected. After the operation the patient lost all symptoms and health returned to normal. The anaemia, hyperglobulinaemia, and abnormal liver function tests resolved, although three years later the erythrocyte sedimentation rate remains slightly raised at 23-35 $\mathrm{mm}$ in the first hour. Histology of the resected tissue showed angiofollicular lymph node hyperplasia of the plasma cell type.
In our patient, as in the patient described by Featherstone $e$ t al, there was a long history of vague ill health and unexplained anaemia, hyperglobulinaemia, and abnormal liver function tests. The diagnostic process was protracted, which is unfortunate in view of the gratifying results of surgical excision. This diagnosis should be considered earlier in a young patient who presents with these features

$$
\begin{array}{r}
\text { I A FINNIE } \\
\text { I T GILMORE } \\
\text { Royal Liverpool Hospital, } \\
\text { Liverpool L } 78 X P
\end{array}
$$

Role of computed tomography, endoscopy, and echoendoscopy in the management of alimentary tract lipomas

SIR, - We read the paper by Kang $e$ t al about the role of computed tomography and endoscopy in the management of alimentary tract lipomas (Gut 1990; 31: 550-3). They describe the management of four cases of alimentary tract lipomas and recommend the use of endoscopy and computed tomography in the diagnosis. Recently it has been stated, in different studies, that echoendoscopy was a better procedure in the assessment of alimentary tract subepithelial tumours than computed tomography, ${ }^{1-3}$ digestive tract lipomas being visualised as a hyperechoïc mass in the digestive tract.' 'Echoendoscopy uses an echographic transducer at the tip of an endoscope. Its use is increasing. We use the side viewing echoendoscope, Olympus EUM3. ${ }^{14}$ With this echoendoscope the exploration of patients 3 and 4 (lipomas of the sigmoid and oesophagus) would have been possible. For patients 1 and 2 (lipomas of colon and ileum) the forward viewing echocoloscope, now available, would also have given a correct diagnosis. In the patients reported on by Kang $e t$ al, the tumours were over $3 \mathrm{~cm}$ in diameter. Some lipomas may be smaller and hardly capable of being seen on computed tomography. Therefore, we think that today the pretherapeutic assessment of alimentary tract lipomas should be done with endoscopy and echoendoscopy. G ROSEAU
J A PAOLAGGI
Hôpital Beaujon,
Service de Gastroentérologie,
100 Bd du Général Leclerc,
92110 Clichy, France

1 Amouyal P, Amouyal G, Palazzo L, et al. L'échoendoscopie: une nouvelle technique d'exploration des tumeurs sous épithéliale. Gastroenterol Clin Biol 1990; 14: 8-14.

2 Silva SH, Kouzot T, Ogino Y, Sato H. Endoscopic ultrasonography of oesophageal tumours and ultrasonography of oesophageal tu

3 Tio TL, Tytgat, GNJ. Atlas of transintestinal ultrasonography. Aalsmeer: Mur-Kosverloren 1986.

4 Palazzo L, Roseau G, Gayet B, Amouyal P, Ponso $P$, Paolaggi JA. L'endosonographie digestive. Presse Méd 1989; 18: 1748-52.

\section{Reply}

SIR, - We thank Drs Roseau and Paolaggi for their comments. We have no personal experience of echoendoscopy but agree that it should be superior to computed tomography in the evaluation of submucosal lesions. This modality, however, unlike computed tomography, is as yet of limited availability. Our comments on computed tomography relate to large lesions since those smaller than $1-2 \mathrm{~cm}$ may not be able to be visualised.

J Y KANG

Division of Gastroenterology Department of Medicin National University Hospital Singapore 051 